
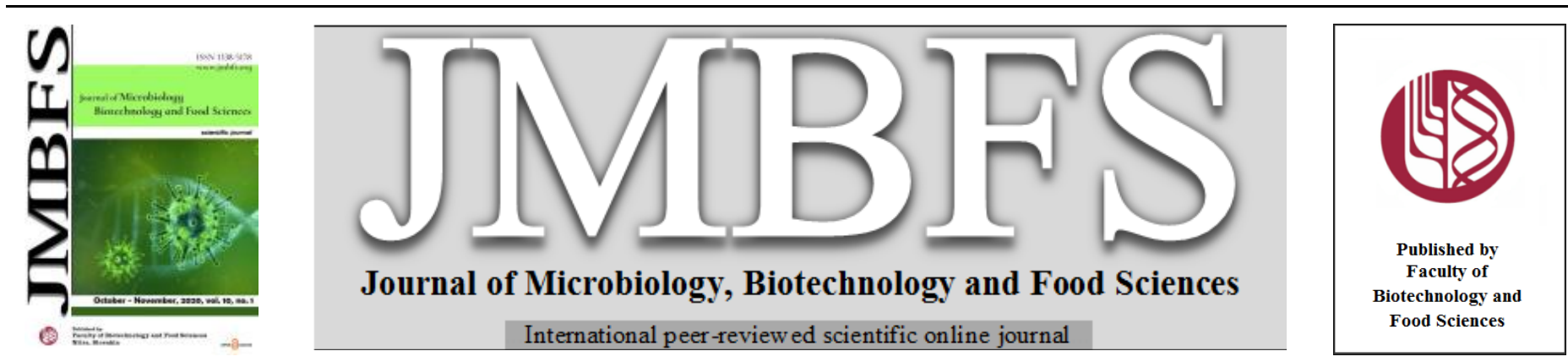

\title{
OPTIMIZATION OF ANTIOXIDANT EXTRACTION FROM KALUMPIT (TERMINALIA MICROCARPA DECNE) FRUITS
}

\author{
Dennis Marvin Santiago*I, Claire Zubial , Shekayna Eunice Pacial, Sheba Mae M. Duque \\ Address(es): Dennis Marvin Santiago, $\mathrm{PhD}$, \\ ${ }^{1}$ University of the Philippines Los Baños, College of Agriculture and Food Science, Institute of Food Science and Technology, 4031 College, Laguna, Philippines, \\ +63495018932 .
}

*Corresponding author: dosantiago1@up.edu.ph

doi: 10.15414/jmbfs.2020.10.2.301-309

\section{ARTICLE INFO}

Received 28. 5. 2020

Revised 19.6. 2020

Accepted 29. 6. 2020

Published 1. 10. 2020

Regular article OPEN $\partial_{\text {AcCESS }}$

\begin{abstract}
The effects of extraction parameters, including temperature $\left(25-80^{\circ} \mathrm{C}\right)$, time $(30-90 \mathrm{~min})$, solvent to sample (S/S) ratio $(10-50 \mathrm{~mL}$ $\left.\mathrm{g}^{-1}\right)$, initial $\mathrm{pH}(3-8)$ and ethanol concentration $(20-100 \%)$, on the \% 2,2-Diphenyl-1-picrylhydrazyl (DPPH) radical scavenging activity of kalumpit were screened and optimized using 2-level factorial design and Box-Behnken design (BBD) of experiments. Temperature, S/S ratio, and ethanol concentration exhibited significant effects on the \% DPPH radical scavenging activity of kalumpit extract. Response surface models developed for \% DPPH and 2,2-azino-bis-3-ethylbenzothiazoline-6-sulfonic acid (ABTS) radical scavenging activities of kalumpit fruit extract adequately fit and were used to determine the optimum extraction conditions. A desirability function approach determined the optimum conditions for solvent extraction of antioxidants at $80.0^{\circ} \mathrm{C}, 10 \mathrm{~mL} \mathrm{~g} \mathrm{~g}^{-1} \mathrm{~S} / \mathrm{S}$, and $51.66 \%$ ethanol concentration. This resulted in a maximum desirability value of 0.977 and predicted \% DPPH and ABTS radical scavenging activities of 66.63 and 82.14 , respectively. Validation of the adequacy of the predictive models showed no significant difference between experimental data and predicted values $(p>0.05)$, indicating that the models developed were adequate in describing the relationship between factors and responses.
\end{abstract}

Keywords: Solvent extraction, 2-level factorial design, Box-Behnken design, DPPH scavenging activity, ABTS scavenging activity

\section{INTRODUCTION}

The Philippines has a variety of edible and nutritious fruits from indigenous trees that are good sources of ethnobotanical ingredients (Dela Cruz, 2012). Traditionally, fruits that contain phytochemicals are being consumed as food and medicine due to the health benefits they bring. However, despite their potential health benefits, the economic significance of these fruits is not yet fully realized; thus, they remain underutilized in terms of food processing. These kinds of fruits are usually seasonal and have a short shelf life. Therefore, it is important to develop processing technologies to fully realize their benefits and extend their availability in the market.

Kalumpit (Terminalia microcarpa Decne.) is one of the endemic, underutilized, and widely distributed fruit trees in the Philippines. It can be found in low altitude forests (Department of Agriculture of the Philippines, 1996; Langenberger et al., 2009; Coronel, 2011). Ragasa et al. (2014) reported that its dichloromethane leaf extract contains squalene, lutein and fatty alcohols that have preventive and therapeutic effects on tumor promotion and regression, and protective effect against inflammatory damage development. Kalumpit fruits can be eaten raw and are used in making wine, jam, and jellies (Sanchez et al., 1976; Ungson, 2001). It is also rich in ascorbic acid, enzymes, bioflavonoid, chromium, potassium, magnesium, B vitamins and amino acids (De Leon, 2012). Moreover, Garcia et al. (2005) reported that kalumpit methanolic fruit extract has antioxidant activity comparable to butylated hydroxytoluene (BHT), butylated hydroxyanisole (BHA), DL- $\alpha$ tocopherol and bignay (Antidesma bunius (L) K. Spreng) fruit in terms of lipid peroxidation inhibition and hydroxyl scavenging activity. It was also verified to have a high total phenolic and flavonoid content that are responsible for its high antioxidant activities (Santiago et al., 2007).

Antioxidants are compounds that can scavenge free-radicals, which if stabilized and accumulated in the body may cause various pathological conditions such as various types of cancer, atherosclerosis, coronary heart disease, rheumatoid arthritis and other degenerative diseases (Ramis-Ramos, 2003). Stabilizing freeradicals is done by means of donating a hydrogen atom to the free-radical to decrease its activation energy, and to prevent it from reacting with other compounds, which in turn produces more free radicals (Pokorny, 2007; Embuscado, 2015; Rodriguez-Amaya, 2015; Shahidi, 2015). Polyphenols are compounds with significant antioxidant activity. The bioactive polyphenols are anthocyanin, flavonoid, isoflavone, phenolic acid and lignin, which exhibit high levels of antioxidant activity (Galili and Hovav, 2014). The extraction of different compounds associated with antioxidant activity may differ through different sources, methods and factors such as the S/S ratio (Yuan et al., 2015), solvent concentration (Chen et al., 2015), extraction temperature (Belwal $\boldsymbol{e t}$ al., 2016), extraction time (Vaji'c et al., 2015) and initial pH (Sharmila et al., 2016). The extraction of bioactive compounds was reported to be highly influenced by the processing parameters employed. The efficiency of extraction is a function of the characteristic of both solvent (e.g. concentration and $\mathrm{pH}$ ) and compound (e.g. particle size, ratio to solvent), and extraction time and temperature (Gertenbach, 2001; Cacace and Mazza, 2003). The extraction process also depends on the diffusion coefficient or how fast the compound will dissolve and reach equilibrium concentration in the solvent, which is influenced by the concentration of the solute, time and temperature (Cacace and Mazza, 2003). Moreover, the denaturation of plant membrane tissues was earlier reported to occur at $55-75^{\circ} \mathrm{C}$ and cannot be increased indefinitely (Schwartzberg and Chao, 1982).

Research on antioxidant extraction were conducted on mangosteen hull (Cheok et al., 2012), blueberry pomace wine (He et al., 2016), pomegranate husk (Amyrgialakia et al., 2014), and fruits of peach (Mokrani and Madani, 2016), apple (Alberti et al., 2014) and pear (Guan et al., 2015) to find natural sources to develop food supplements and functional food products (Silva et al., 2007). This research on kalumpit is vital to establish baseline data prior to the utilization of this crop and maximize its potential. Aside from food products that can be developed from kalumpit, high value ingredients, such as antioxidants and colorants, can also be extracted for use in various industries.

In order to maximize antioxidant extraction, the optimization of various parameters and conditions that can affect the extraction process should be performed. The traditional way of screening variables is the "one-variable-at-a time' concept that has been shown to work well when applied to process designs, especially in cases where a small number of variables are being studied. However, this may become a problem when applied to an experiment that needs to consider a large number of variables. This traditional method is time consuming, expensive and does not allow the understanding of the interactions between the factors considered (Weuster-Botz, 2000). Response surface 
methodology (RSM) can be a better alternative due to its efficiency and practicality. It utilizes mathematical and statistical techniques in the creation of models for the analysis in which the response of concern can be affected by the numbers of known variables. In a way, those variables are used to attain the goal of optimal results (Montgomery, 2013).

This study fundamentally aimed to optimize the extraction protocol for antioxidants from kalumpit fruit. Specifically, this study intended to screen factors (temperature, time, $\mathrm{S} / \mathrm{S}$ ratio, initial $\mathrm{pH}$ and ethanol concentration) that significantly affect the antioxidant activity of kalumpit extract using 2-leve factorial experimental design; optimize levels of significant factors that affect DPPH and ABTS radical scavenging activities using Box-Behnken design of experiment; and validate the optimized extraction parameters generated.

\section{MATERIAL AND METHODS}

\section{Sample Preparation}

Mature kalumpit fruits were obtained from the Fruit Crops Nursery, Institute of Crop Science, College of Agriculture and Food Science, University of the Philippines Los Baños. Fruits were immediately washed, cut to obtain the flesh, dried at $50{ }^{\circ} \mathrm{C}$ for 72 hours, ground, and passed through a 40-mesh sieve. Samples were then stored in an amber or foil-covered bottle under freezing temperature until use.

\section{Chemicals}

Absolute ACS/USP Grade Ethyl alcohol (PHARMCO-AAPER, Connecticut, USA), 2,2-Diphenyl-1-picrylhydrazyl (DPPH), and 2,2-azino-bis-3ethylbenzothiazoline 6-sulfonic acid (ABTS) (Sigma Aldrich Pte. Ltd, Singapore, Singapore) were used in this study.

\section{Screening of Factors for Antioxidant Extraction}

A randomized 2-level factorial experimental design was generated using Design Expert version 10.0.3 (Stat-Ease, Inc., Minnesota, USA) to screen which among the considered factors significantly affect antioxidant extraction from kalumpit. Varying levels of temperature $\left(25,52.5,80^{\circ} \mathrm{C}\right)$, extraction time $(30,60,90 \mathrm{~min})$ $\mathrm{S} / \mathrm{S}$ ratio $\left(10,30,50 \mathrm{~mL} \mathrm{~g}^{-1}\right), \mathrm{pH}(3,5.5,8)$ and \% ethanol $(20,60,100 \%)$ were considered based on previous studies of Chew et al. (2011), Vaji'c et al. (2015) and Belwal et al. (2016). Table 1 shows the different factors considered, in uncoded levels, consisting of 35 experimental points, including 3 replicates of the center points.

Extraction of antioxidants from kalumpit powder was conducted according to Belwal et al. (2016), with minor modifications. Approximately $1 \mathrm{~g}$ of kalumpit powder was weighed into 50-mL centrifuge tubes, added with ethanol (varying amounts and concentration), and adjusted to its corresponding initial $\mathrm{pH}$. The mixture was then thoroughly mixed using a vortex mixer for 2 minutes and incubated in water bath (varying temperature and time). Samples were then filtered through Whatman no. 2 filter paper and the collected extract was analyzed for its DPPH radical scavenging activity.

\section{Optimization and Validation of Significant Factors for Antioxidan Extraction}

After identifying the significant factors that influence antioxidant extraction, Box-Behnken Design (BBD) was employed to establish the optimal values of these factors, based on the maximum percentage of DPPH radical scavenging activity of kalumpit fruit extract. Design Expert version 10.0.3 was used to generate the model and analyze the results of the experiment. Table 2 shows the different factors, in uncoded levels, to determine the optimal levels of identified significant factors for maximum antioxidant extraction. Evaluation of \% DPPH was conducted. At the same time, an additional assessment by ABTS radica scavenging activities was carried out as a complementary test. The desirability function of Design Expert version 10.0.3, which is a unique and powerful multiresponse (multivariate) optimization tool, was used to determine the optimum conditions for extraction of kalumpit with optimum of \% DPPH and ABTS radical scavenging activities. To validate the predictive ability and accuracy of the models developed, three replications at optimum conditions were carried out and compared with the predicted values.

\section{Analysis of Antioxidant Property}

The 2,2-Diphenyl-1-picrylhydrazyl (DPPH) assay, according to Zhu et al (2002), was used to determine the radical scavenging activity of kalumpit extract. Particularly, $1 \mathrm{mM}$ solution of DPPH was prepared in absolute ethanol. A $1 \mathrm{~mL}$ aliquot of diluted extract (dilution factor $=30$ ) in $52 \%$ ethanol was mixed with 4 $\mathrm{mL}$ distilled water and $1 \mathrm{~mL}$ of the freshly prepared $\mathrm{DPPH}$ ethanolic solution. The mixture was placed in a dark room for 30 minutes. The absorbance was measured at $517 \mathrm{~nm}$ against a blank using UV-VIS spectrophotometer Shimadzu
UVmini-1240 (Kyoto, Japan). All measurements were carried out in triplicate. The \% DPPH radical scavenging activity was calculated using equation 1:

$$
\begin{gathered}
\% \text { DPPH radical scavenging activity }= \\
\frac{A_{0}-A_{t}}{A_{0}} \times 100 \% \\
\text { Equation 1 }
\end{gathered}
$$

where $A_{0}$ represents the absorbance of control reference at $t=0$ min while $A_{t}$ represents the absorbance of the samples.

The ABTS (2,2-azino-bis-3-ethylbenzothiazoline 6-sulfonic acid) free radical scavenging activity of the extract was measured using the method described by Re et al. (1999). The ABTS stock solution was prepared by mixing $7 \mathrm{mM}$ ABTS with $2.45 \mathrm{mM}$ potassium persulfate and incubated for 16 hours in the dark at 30 ${ }^{\circ} \mathrm{C}$. An aliquot of the stock solution was diluted with methanol to adjust the absorbance to $0.70 \pm 0.02$ at $734 \mathrm{~nm}$. A $20 \mu \mathrm{L}$ aliquot of diluted extract (dilution factor $=30$ ) was added with $980 \mu \mathrm{L}$ ABTS reagent. The absorbance of the resulting solution was read at $734 \mathrm{~nm}$ using a UV-VIS spectrophotometer Shimadzu UVmini-1240 (Kyoto, Japan) after 1 minute. The antioxidant activity of the extract was calculated against a calibration curve $(0,5,10,15,20,25,30$, $35,40 \mu \mathrm{M})$ established with Trolox $\left(\mathrm{R}^{2}=0.998\right)$, and expressed as mg Trolox equivalent per $100 \mathrm{~g}$ purée. Results were expressed as \% ABTS scavenging activity using equation 2 :

\%ABTS Scavenging Activity

$$
=\left(1-\frac{\text { Absorbance sample }_{\text {sance }}}{\text { Absorbank }}\right) \times 100
$$

\section{Statistical data analysis}

Equation 2

All statistical analyses were performed using Design Expert version 10.0.3 software (Stat-Ease, Inc., Minnesota, USA) to analyze the experimental data and the response surface model for screening and optimization of significant factors affecting \% DPPH and ABTS radical scavenging activities. Design Expert version 10.0.3 software was also used to determine the Analysis of Variance (ANOVA) and coefficient of determination $\left(\mathrm{R}^{2}\right)$, and to evaluate the goodness of fit of the model. The validity of the model was determined by comparing the observed experimental and predicted values for the response variables with t-test analysis using Minitab version 18.1 (Minitab Pty Ltd, Sydney, Australia).

\section{RESULTS AND DISCUSSION}

\section{Screening of Factors for Antioxidant Extraction}

A 2-level factorial experimental design, with three-level factor, was employed to screen the extraction factors that significantly affects DPPH radical scavenging activities of kalumpit extract. Table 1 shows the DPPH radical scavenging activities of kalumpit extracted using different extraction conditions. The mode as described in Equation 3, achieved an $\mathrm{R}^{2}$ value of 0.8671 , indicating that 86.71 $\%$ of the proportion of the variability in the response can be explained by the model. Moreover, the high value of $\mathrm{R}^{2}$ (values $>0.70$ ) is indicative that the model is fitting the data very well. A standard deviation value of 3.06 apart from the fitted values, which is only $4.62 \%$ of the mean $(66.08 \%)$, signifies a precise description of the response. Nevertheless, the model assumption cannot be validated completely through this value, hence the need for further statistical analyses.

DPPH Scavenging Activity $=+66.08+1.96 \mathrm{~A}+0.40 \mathrm{~B}-2.15 \mathrm{C}-0.11 \mathrm{D}-1.97 \mathrm{E}$ $+0.60 \mathrm{AC}+0.29 \mathrm{AD}+0.64 \mathrm{AE}-0.96 \mathrm{BC}+0.66 \mathrm{BD}$

$-0.05 \mathrm{BE}-0.49 \mathrm{CD}-1.41 \mathrm{CE}-0.29 \mathrm{DE}-0.43 \mathrm{ACD}-0.17 \mathrm{ACE}+0.75 \mathrm{ADE}-1.64 \mathrm{BCE}$ $+1.13 \mathrm{BDE}-0.58 \mathrm{CDE}+1.62 \mathrm{ACDE} \quad$ Equation 3

Where $\mathrm{A}, \mathrm{B}, \mathrm{C}, \mathrm{D}$, and $\mathrm{E}$ denote temperature, time, $\mathrm{S} / \mathrm{S}$ ratio, $\mathrm{pH}$ and $\%$ ethanol concentration, respectively.

Table 2 shows the analysis of variance (ANOVA), model summary, coefficient estimate and the effects of the selected factorial model for screening of factors that significantly affect the antioxidant activity of the kalumpit extract. The Fvalue of 4.04 implies that the model is significant and there is only a $0.63 \%$ chance that an F-value this large could occur due to noise $(p<0.05)$. The "Lack of Fit F-value" of 0.84 implies the Lack of Fit is not significant relative to the pure error and that there is a $65.93 \%$ chance that a "Lack of Fit F-value" this large could occur due to noise $(p>0.05)$. The non-significant lack of fit indicates that the model fits and the "Adeq Precision" of 8.985 value, which is greater than 4 , is suggestive of an adequate signal. Therefore, the model generated can be used to navigate the design space.

A significant effect $(p<0.05)$ on the $\%$ DPPH radical scavenging activity of kalumpit extract was exhibited by temperature, $\mathrm{S} / \mathrm{S}$ ratio, $\%$ ethanol concentration, two-factorial interaction of $\mathrm{S} / \mathrm{S}$ ratio and \% ethanol concentration, 
three-factorial interactions of time, $\mathrm{S} / \mathrm{S}$ ratio and \% ethanol concentration, and four-factorial interaction of temperature, $\mathrm{S} / \mathrm{S}$ ratio, $\mathrm{pH}$ and $\%$ ethanol concentration. The effect of individual factors, presented in Table 2, describes that the greater degree of effect is signified by a higher value. Temperature had the highest positive effect value among all the factors and interactions with $13 \%$ contribution. The antioxidant activity of kalumpit extract increased when the temperature was increased because heat enhances the diffusivity of extraction solvents into plant cells and stimulates higher solubility of phenolic compounds in the extraction solvent (Chew et al., 2011). Similarly, the four-factoria interaction of temperature, $\mathrm{S} / \mathrm{S}$ ratio, $\mathrm{pH}$ and $\%$ ethanol concentration had significant positive effect on \% DPPH scavenging activities of kalumpit extract with $9.19 \%$ contribution. In contrast, S/S ratio and \% ethanol had a high degree of negative effect with 16.19 and $13.55 \%$ contribution, respectively. The observed decrease in the antioxidant activity of kalumpit extract, when the S/S ratio was increased, may be due to the limited amount of extractable phenolic compounds (Rezaei et al., 2013). On the other hand, the observed negative effect of ethanol concentration is similar to the result reported by $\mathbf{L i}$ et al. (2019), wherein, an increase in the ethanol concentration from $20 \%$ to $40 \%$ increased the antioxidant activity of Gordonia axillaris extract and gradually decreased when the concentration was increased further to $80 \%$. Increasing the volume of ethanol in water increases its polarity. Thus, in the case of kalumpit extract, it is possible that most of the phenolic compounds present are moderately polar. Furthermore, in the extraction of bioactive components, the use of a binary solvent system is found to be more favorable since water and alcohol can work in synergy. Water can swell the plant matrix, thereby increasing the contact surface area between the solvent and the plant matrix (Alara et al., 2017).

The two-factorial interaction of $\mathrm{S} / \mathrm{S}$ ratio and \% ethanol concentration, threefactorial interaction time, $\mathrm{S} / \mathrm{S}$ ratio and \% ethanol concentration also had significant negative effects with 6.9 and $9.47 \%$ contribution, respectively. With this, temperature, $\mathrm{S} / \mathrm{S}$ ratio and \% ethanol concentration were the significant factors considered for the optimization of antioxidant extraction from kalumpit Similarly, Belwal et al. (2016) reported that the effects of extraction temperature, $\mathrm{S} / \mathrm{S}$ ratio, and solvent concentration significantly affect the antioxidant activities of Berberis asiatica fruits using ABTS, FRAP and DPPH Assays. Moreover, the same variables were optimized by Karacabey and Mazza (2010) and Ilaiyaraja et al. (2015) on the extraction of phenolic compounds with high antioxidant activity from grape cane and wood apple, respectively.

\section{Response surface model of \% DPPH radical scavenging activity of Kalumpit Extract}

Optimization of the extraction process was carried out by applying the BoxBehnken design as shown in the experimental data in Table 3. Table 4 shows the model for \% DPPH radical scavenging activity with an $\mathrm{R}^{2}$ of 0.9147 which indicates that $91.47 \%$ of the proportion of variability in the response can be attributed to the model. Design Expert version 10.0.3 suggested a quadratic model represented by Equation 4. The Model F-value of 39.34 implies that the model was significant $(p<0.05)$ with a $0.01 \%$ chance that an F-value this large could occur due to noise. The "Lack of Fit F-value" of 0.77 implies that the Lack of Fit was not significant $(p>0.05)$ relative to the pure error and there was a $70.87 \%$ chance that a "Lack of Fit F-value" this large could occur due to noise. The model's Adeq precision of 21.031 indicates an adequate signal to noise ratio and that the model can be used to navigate the design space.

$\%$ DPPH Scavenging Activity $=+62.69+1.15 \mathrm{~A}-3.70 \mathrm{~B}-7.23 \mathrm{C}+0.35 \mathrm{AB}-0.35 \mathrm{AC}$ $-5.32 \mathrm{BC}+0.13 \mathrm{~A}^{2}-0.87 \mathrm{~B}^{2}-6.89 \mathrm{C}^{2}$

Equation 4

Where $\mathrm{A}, \mathrm{B}$, and $\mathrm{C}$ denote temperature, $\mathrm{S} / \mathrm{S}$ ratio and $\%$ ethanol concentration, respectively.

Table 12 -level factorial experimental design for the screening of factors affecting the antioxidant activity of kalumpit extract

\begin{tabular}{|c|c|c|c|c|c|c|c|}
\hline $\begin{array}{c}\text { Standard } \\
\text { Order }\end{array}$ & $\begin{array}{l}\text { Run } \\
\text { Order }\end{array}$ & $\begin{array}{c}\text { Temperature } \\
\left({ }^{\circ} \mathrm{C}\right)\end{array}$ & $\begin{array}{l}\text { Time } \\
(\mathrm{min})\end{array}$ & $\begin{array}{c}\text { Solvent to } \\
\text { Sample Ratio } \\
(\mathrm{mL} \cdot \mathrm{g}-1)\end{array}$ & pH & $\begin{array}{c}\text { Ethanol } \\
\text { Concentration } \\
(\%)\end{array}$ & $\begin{array}{c}\text { DPPH } \\
\text { Radical } \\
\text { Scavenging } \\
\text { Activity (\%) } \\
\end{array}$ \\
\hline 35 & 1 & 52.5 & 60 & 30 & 5.5 & 60 & 74.07 \\
\hline 28 & 2 & 80 & 90 & 10 & 8 & 100 & 73.88 \\
\hline 21 & 3 & 25 & 30 & 50 & 3 & 100 & 65.5 \\
\hline 10 & 4 & 80 & 30 & 10 & 8 & 20 & 71.64 \\
\hline 27 & 5 & 25 & 90 & 10 & 8 & 100 & 70.18 \\
\hline 32 & 6 & 80 & 90 & 50 & 8 & 100 & 66.18 \\
\hline 19 & 7 & 25 & 90 & 10 & 3 & 100 & 64.81 \\
\hline 18 & 8 & 80 & 30 & 10 & 3 & 100 & 65.79 \\
\hline 8 & 9 & 80 & 90 & 50 & 3 & 20 & 72.51 \\
\hline 15 & 10 & 25 & 90 & 50 & 8 & 20 & 68.03 \\
\hline 2 & 11 & 80 & 30 & 10 & 3 & 20 & 68.13 \\
\hline 1 & 12 & 25 & 30 & 10 & 3 & 20 & 67.64 \\
\hline 3 & 13 & 25 & 90 & 10 & 3 & 20 & 71.05 \\
\hline 20 & 14 & 80 & 90 & 10 & 3 & 100 & 72.03 \\
\hline 22 & 15 & 80 & 30 & 50 & 3 & 100 & 67.15 \\
\hline 13 & 16 & 25 & 30 & 50 & 8 & 20 & 67.15 \\
\hline 9 & 17 & 25 & 30 & 10 & 8 & 20 & 67.06 \\
\hline 14 & 18 & 80 & 30 & 50 & 8 & 20 & 65.5 \\
\hline 11 & 19 & 25 & 90 & 10 & 8 & 20 & 65.6 \\
\hline 16 & 20 & 80 & 90 & 50 & 8 & 20 & 68.03 \\
\hline 33 & 21 & 52.5 & 60 & 30 & 5.5 & 60 & 67.74 \\
\hline 12 & 22 & 80 & 90 & 10 & 8 & 20 & 69.59 \\
\hline 23 & 23 & 25 & 90 & 50 & 3 & 100 & 56.14 \\
\hline 26 & 24 & 80 & 30 & 10 & 8 & 100 & 66.08 \\
\hline 29 & 25 & 25 & 30 & 50 & 8 & 100 & 55.26 \\
\hline 17 & 26 & 25 & 30 & 10 & 3 & 100 & 63.74 \\
\hline 7 & 27 & 25 & 90 & 50 & 3 & 20 & 63.65 \\
\hline 34 & 28 & 52.5 & 60 & 30 & 5.5 & 60 & 69.4 \\
\hline 5 & 29 & 25 & 30 & 50 & 3 & 20 & 60.43 \\
\hline 6 & 30 & 80 & 30 & 50 & 3 & 20 & 69.98 \\
\hline 30 & 31 & 80 & 30 & 50 & 8 & 100 & 61.7 \\
\hline 24 & 32 & 80 & 90 & 50 & 3 & 100 & 57.7 \\
\hline 4 & 33 & 80 & 90 & 10 & 3 & 20 & 66.37 \\
\hline 25 & 34 & 25 & 30 & 10 & 8 & 100 & 61.7 \\
\hline 31 & 35 & 25 & 90 & 50 & 8 & 100 & 51.56 \\
\hline
\end{tabular}


Table 2 Analysis of variance, model summary, and estimated effects of selected factorial model affecting antioxidant activity of kalumpit extract

\begin{tabular}{|c|c|c|c|c|c|c|c|c|}
\hline Source/Factor & $\begin{array}{c}\text { Sum of } \\
\text { Squares }\end{array}$ & df & $\begin{array}{c}\text { Mean } \\
\text { Square }\end{array}$ & $\begin{array}{c}\text { F } \\
\text { Value } \\
\end{array}$ & $\begin{array}{c}\text { p-value } \\
\text { Prob > F }\end{array}$ & $\begin{array}{c}\text { Coefficient } \\
\text { Estimate }\end{array}$ & $\begin{array}{c}\text { Standardized } \\
\text { Effect }\end{array}$ & $\begin{array}{c}\% \\
\text { Contribution }\end{array}$ \\
\hline Model & 792.59 & 21 & 37.74 & 4.4 & 0.0063 & & & \\
\hline $\begin{array}{l}\text { A- } \\
\text { Temperature }\end{array}$ & 123.12 & 1 & 123.12 & 13.18 & 0.0030 & 1.96 & 3.92 & 13.47 \\
\hline B-Time & 5.17 & 1 & 5.17 & 0.55 & 0.4700 & 0.4 & 0.80 & 0.57 \\
\hline $\begin{array}{l}\text { C-Solvent to } \\
\text { Sample Ratio }\end{array}$ & 147.97 & 1 & 147.97 & 15.84 & 0.0016 & -2.15 & -4.30 & 16.19 \\
\hline $\mathrm{D}-\mathrm{pH}$ & 0.38 & 1 & 0.38 & 0.041 & 0.8423 & -0.11 & -0.22 & 0.042 \\
\hline $\begin{array}{l}\text { E- Ethanol } \\
\text { Conc. }\end{array}$ & 123.89 & 1 & 123.89 & 13.26 & 0.0030 & -1.97 & -3.94 & 13.55 \\
\hline $\mathrm{AC}$ & 11.64 & 1 & 11.64 & 1.25 & 0.2845 & 0.6 & 1.21 & 1.27 \\
\hline $\mathrm{AD}$ & 2.74 & 1 & 2.74 & 0.29 & 0.5975 & 0.29 & 0.59 & 0.3 \\
\hline $\mathrm{AE}$ & 13.9 & 1 & 13.9 & 1.4 & 0.2577 & 0.64 & 1.28 & 1.43 \\
\hline $\mathrm{BC}$ & 29.27 & 1 & 29.27 & 3.13 & 0.1001 & -0.96 & -1.91 & 3.2 \\
\hline $\mathrm{BD}$ & 13.85 & 1 & 13.85 & 1.48 & 0.2450 & 0.66 & 1.32 & 1.52 \\
\hline $\mathrm{BE}$ & 0.096 & 1 & 0.096 & 0.01 & 0.9207 & -0.055 & -0.11 & 0.011 \\
\hline $\mathrm{CD}$ & 7.79 & 1 & 7.79 & 0.83 & 0.3777 & -0.49 & -0.99 & 0.85 \\
\hline $\mathrm{CE}$ & 63.91 & 1 & 63.91 & 6.84 & 0.0214 & -1.41 & -2.83 & 6.99 \\
\hline DE & 2.62 & 1 & 2.62 & 0.28 & 0.6051 & -0.29 & -0.57 & 0.29 \\
\hline $\mathrm{ACD}$ & 5.99 & 1 & 5.99 & 0.64 & 0.4378 & -0.43 & -0.87 & 0.65 \\
\hline $\mathrm{ACE}$ & 0.93 & 1 & 0.93 & 0.1 & 0.7572 & -0.17 & -0.34 & 0.1 \\
\hline $\mathrm{ADE}$ & 17.96 & 1 & 17.96 & 1.92 & 0.1888 & 0.75 & 1.50 & 1.97 \\
\hline $\mathrm{BCE}$ & 86.57 & 1 & 86.57 & 9.27 & 0.0094 & -1.64 & -3.29 & 9.47 \\
\hline $\mathrm{BDE}$ & 40.64 & 1 & 40.64 & 4.35 & 0.0573 & 1.13 & 2.25 & 4.45 \\
\hline $\mathrm{CDE}$ & 10.94 & 1 & 10.94 & 1.17 & 0.2988 & -0.58 & -1.17 & 1.2 \\
\hline ACDE & 84.02 & 1 & 84.02 & 8.99 & 0.0103 & 1.62 & 3.24 & 9.19 \\
\hline Residual & 121.43 & 13 & 9.34 & & & & & \\
\hline Lack of Fit & 99.84 & 11 & 9.8 & 0.84 & 0.6593 & & & \\
\hline Pure Error & 21.59 & 2 & 10.79 & & & & & \\
\hline Cor Total & 914.02 & 34 & & & & & & \\
\hline \multicolumn{9}{|l|}{$\begin{array}{l}\text { Model } \\
\text { Summary }\end{array}$} \\
\hline Std. Dev. & 3.6 & & \multicolumn{3}{|c|}{ R-Squared } & 0.8671 & $\begin{array}{c}\text { Adeq } \\
\text { Precision }\end{array}$ & 8.985 \\
\hline Mean & 66.08 & & \multirow{2}{*}{\multicolumn{3}{|c|}{$\begin{array}{l}\text { Adj R-Squared } \\
\text { Pred R-Squared }\end{array}$}} & 0.6525 & BIC & 221.08 \\
\hline C.V. $\%$ & 4.62 & & \multicolumn{2}{|c|}{ Pred R-Squared } & & 0.4266 & $\mathrm{AICc}$ & 271.2 \\
\hline PRESS & 524.13 & & \multicolumn{3}{|c|}{-2 Log Likelihood } & 142.87 & & \\
\hline
\end{tabular}

Table 4 shows that the linear terms of temperature, $\mathrm{S} / \mathrm{S}$ ratio, ethanol concentration, interactive effect of $\mathrm{S} / \mathrm{S}$ ratio, ethanol concentration, and quadratic effect of ethanol concentration were found to significantly affect the \% DPPH radical scavenging activity of the kalumpit extract $(p<0.05)$. The significant linear effects of extraction temperature and ethanol concentration on the \% DPPH radical scavenging activity are consistent with the reports of Belwal et al. (2016), Ilaiyaraja et al. (2015), Karacabey and Mazza (2010), and Li et al. (2012) on the antioxidant extraction from Berberis asiatica fruits, wood apple, grape, and tomato, respectively. On the other hand, the quadratic effect of ethanol concentration agrees with the report of Belwal et al. (2016) on the significant quadratic effect of solvent on FRAP activity of Berberis asiatica fruit extract.

Positive values of coefficients indicate a positive effect on the response variable while negative coefficients indicate the opposite. Higher coefficient values indicate greater contribution to the response. In this regard, extraction temperature had a significant positive effect on the \% DPPH radical scavenging activity of kalumpit extract $(p<0.05$ ), demonstrated by its coefficient estimate of 1.15 (Table 4) and as shown in Figure 1A. It can be observed that high level of temperature $\left(80^{\circ} \mathrm{C}\right)$ resulted in high \% DPPH scavenging activity. This can be attributed to the higher diffusion coefficient of phenolic compounds, resulting in high solubility and extraction rate (Ju and Howard, 2003; Pompeu et al., 2009; Piovesan et al., 2017). This result agrees with several studies that reported on the positive effect of increasing extraction temperature on antioxidant activity (Vatai et al. 2009; Li et al., 2012; Benmeziane et al. 2013; Piovesan et al., 2017).

On the other hand, linear effect of $\mathrm{S} / \mathrm{S}$ ratio was found to have significan negative effect $(p<0.05)$ on \% DPPH scavenging activity of kalumpit extract as shown in Table 4 and Figure 1B. It can be observed that low level S/S ratio (10
$\mathrm{mL} / \mathrm{g}$ ) resulted in high \% DPPH scavenging activity. The significant negative effect of S/S ratio in this study is consistent with the findings of KemerliKalbaran and Ozdemir (2019) on the optimization of DPPH scavenging activities of lipophilic and hydrophilic phase, and oil of pine nut.

The linear and quadratic effects of ethanol concentration were observed to have significant negative effects on \% DPPH scavenging activity of kalumpit extract as shown in Table 4 and Figure 1C. In this regard, ethanol concentration near the midpoint level resulted in high \% DPPH scavenging activity. Among interactive effects, only the interaction of S/S ratio and ethanol concentration was found to have significant negative effects as shown in Table 4 . Figure $2 \mathrm{C}$ shows that high $\%$ DPPH scavenging activity can be observed in low-level $\mathrm{S} / \mathrm{S}$ ratio and midpoint-level of ethanol concentration. The significant negative effect of ethanol concentration, in quadratic term, is consistent with the report of Lee et al. (2016) on \% DPPH scavenging activity of Korean red ginseng. Increasing ethanol concentration up to the midpoint level results in reduced dielectric constant of the solution and energy needed to separate solvent molecules, allowing solutes to easily dissolve in the solvent (Cacace and Mazza, 2002, 2003; Pompeu et al., 2009)

The interaction of temperature and $\mathrm{S} / \mathrm{S}$ ratio had a positive effect while the interaction of $\mathrm{S} / \mathrm{S}$ ratio and ethanol concentration showed negative effect as shown in Table 4. However, both effects were not significant. Figure 2A shows that high \% DPPH scavenging activity can be observed in high-level extraction temperature and low-level S/S ratio. Moreover, Figure 2B shows that a high \% DPPH scavenging activity can be observed in high-level extraction temperature and midpoint-level of ethanol concentration. 
Table 3 Box-Behnken design for optimization of DPPH and ABTS scavenging activities of kalumpit extract

\begin{tabular}{|c|c|c|c|c|c|c|c|}
\hline Standard & Block & Order & $\left({ }^{\circ} \mathrm{C}\right)$ & $\begin{array}{c}\text { Solvent to } \\
\text { Sample Ratio } \\
\left(\mathrm{mL} \cdot \mathrm{g}^{-1}\right)\end{array}$ & $\begin{array}{c}\begin{array}{c}\text { Ethanol } \\
\text { Concentration }\end{array} \\
(\%)\end{array}$ & $\begin{array}{c}\text { DPPH } \\
\text { Radical } \\
\text { Scavenging } \\
\text { Activity } \\
(\%)\end{array}$ & $\begin{array}{c}\text { ABTS } \\
\text { Scavenging } \\
\text { Activity } \\
(\%)\end{array}$ \\
\hline 7 & 1 & 1 & 25 & 30 & 100 & 53.08 & 2.50 \\
\hline 1 & 1 & 2 & 25 & 10 & 60 & 62.31 & 66.43 \\
\hline 6 & 1 & 3 & 80 & 30 & 20 & 65.38 & 52.86 \\
\hline 9 & 1 & 4 & 52.5 & 10 & 20 & 59.62 & 79.64 \\
\hline 13 & 1 & 5 & 52.5 & 30 & 60 & 63.08 & 76.43 \\
\hline 10 & 1 & 6 & 52.5 & 50 & 20 & 62.31 & 21.79 \\
\hline 11 & 1 & 7 & 52.5 & 10 & 100 & 61.54 & 26.43 \\
\hline 5 & 1 & 8 & 25 & 30 & 20 & 62.69 & 5.36 \\
\hline 2 & 1 & 9 & 80 & 10 & 60 & 65.38 & 78.93 \\
\hline 12 & 1 & 10 & 52.5 & 50 & 100 & 38.08 & 5.71 \\
\hline 14 & 1 & 11 & 52.5 & 30 & 60 & 55.00 & 56.79 \\
\hline 15 & 1 & 12 & 52.5 & 30 & 60 & 62.31 & 34.64 \\
\hline 8 & 1 & 13 & 80 & 30 & 100 & 46.54 & 13.57 \\
\hline 4 & 1 & 14 & 80 & 50 & 60 & 60.77 & 41.43 \\
\hline 3 & 1 & 15 & 25 & 50 & 60 & 57.69 & 2.50 \\
\hline 31 & 2 & 16 & 25 & 10 & 60 & 63.46 & 77.14 \\
\hline 44 & 2 & 17 & 52.5 & 30 & 60 & 63.46 & 76.79 \\
\hline 43 & 2 & 18 & 52.5 & 30 & 60 & 62.31 & 50.71 \\
\hline 33 & 2 & 19 & 25 & 50 & 60 & 58.08 & 8.93 \\
\hline 38 & 2 & 20 & 80 & 30 & 100 & 49.23 & 31.43 \\
\hline 41 & 2 & 21 & 52.5 & 10 & 100 & 56.92 & 30.36 \\
\hline 40 & 2 & 22 & 52.5 & 50 & 20 & 60.77 & 17.14 \\
\hline 42 & 2 & 23 & 52.5 & 50 & 100 & 39.23 & 4.29 \\
\hline 35 & 2 & 24 & 25 & 30 & 20 & 62.69 & 19.64 \\
\hline 36 & 2 & 25 & 80 & 30 & 20 & 63.85 & 46.43 \\
\hline 45 & 2 & 26 & 52.5 & 30 & 60 & 63.08 & 41.79 \\
\hline 34 & 2 & 27 & 80 & 50 & 60 & 59.62 & 23.57 \\
\hline 39 & 2 & 28 & 52.5 & 10 & 20 & 61.15 & 79.64 \\
\hline 32 & 2 & 29 & 80 & 10 & 60 & 65.77 & 79.29 \\
\hline 37 & 2 & 30 & 25 & 30 & 100 & 43.85 & 3.57 \\
\hline 21 & 3 & 31 & 80 & 30 & 20 & 67.69 & 34.64 \\
\hline 26 & 3 & 32 & 52.5 & 10 & 100 & 58.46 & 11.43 \\
\hline 18 & 3 & 33 & 25 & 50 & 60 & 57.69 & 18.93 \\
\hline 19 & 3 & 34 & 80 & 50 & 60 & 62.69 & 30.71 \\
\hline 28 & 3 & 35 & 52.5 & 30 & 60 & 67.69 & 70.71 \\
\hline 30 & 3 & 36 & 52.5 & 30 & 60 & 64.23 & 63.57 \\
\hline 29 & 3 & 37 & 52.5 & 30 & 60 & 63.08 & 37.86 \\
\hline 25 & 3 & 38 & 52.5 & 50 & 20 & 61.54 & 15.36 \\
\hline 16 & 3 & 39 & 25 & 10 & 60 & 65.00 & 51.79 \\
\hline 17 & 3 & 40 & 80 & 10 & 60 & 65.00 & 75.36 \\
\hline 23 & 3 & 41 & 80 & 30 & 100 & 49.23 & 27.14 \\
\hline 24 & 3 & 42 & 52.5 & 10 & 20 & 61.15 & 82.14 \\
\hline 20 & 3 & 43 & 25 & 30 & 20 & 63.08 & 4.29 \\
\hline 27 & 3 & 44 & 52.5 & 50 & 100 & 38.46 & 12.14 \\
\hline 22 & 3 & 45 & 25 & 30 & 100 & 43.85 & 5.00 \\
\hline
\end{tabular}
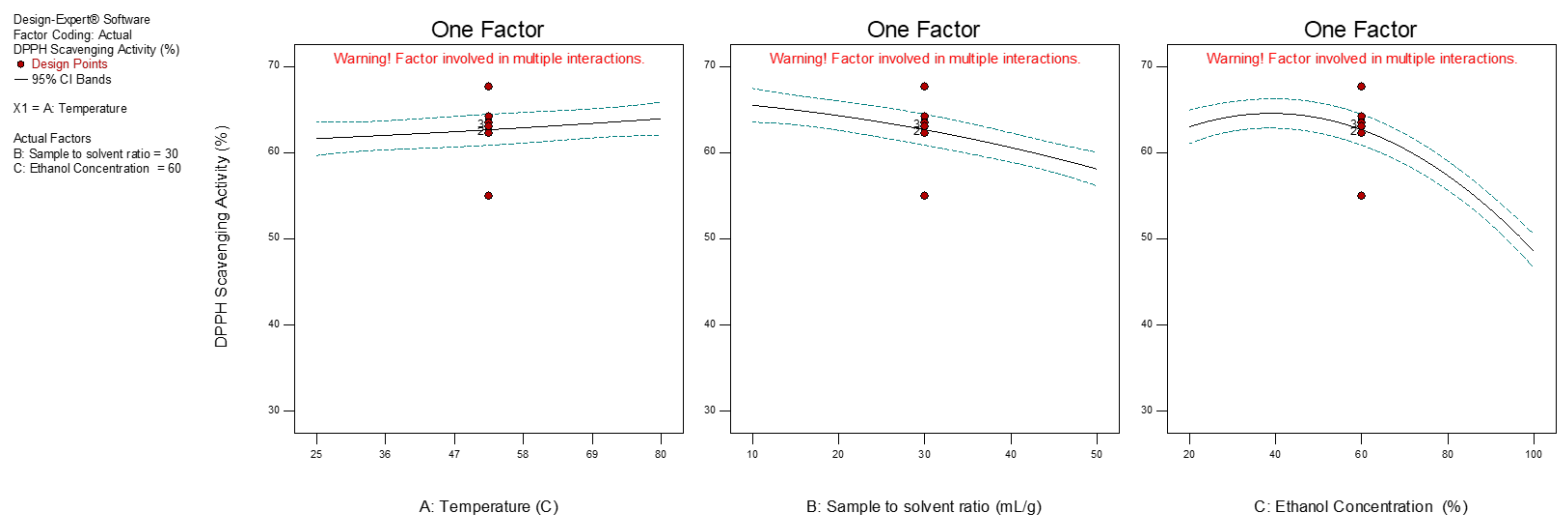

Figure 1 Model graphs for linear effects of extraction temperature (A), S/S ratio (B) and ethanol concentration (C) on \% DPPH scavenging activity of kalumpit extract 
Table 4 Analysis of variance and model summary for response surface quadratic model for \% DPPH scavenging activity of kalumpit extract

\begin{tabular}{|c|c|c|c|c|c|c|}
\hline Source & $\begin{array}{l}\text { Sum of } \\
\text { Squares }\end{array}$ & df & $\begin{array}{l}\text { Mean } \\
\text { Square }\end{array}$ & F Value & $\begin{array}{c}\text { p-value } \\
\text { Prob > F }\end{array}$ & $\begin{array}{c}\text { Coefficient } \\
\text { Estimate }\end{array}$ \\
\hline Block & 9.18 & 2 & 4.59 & & & \\
\hline Model & 2489.7 & 9 & 276.63 & 39.34 & $<0.0001$ & \\
\hline $\begin{array}{l}\text { A- } \\
\text { Temperature }\end{array}$ & 31.95 & 1 & 31.95 & 4.54 & 0.0406 & 1.15 \\
\hline $\begin{array}{l}\text { B-Solvent to } \\
\text { Sample Ratio }\end{array}$ & 328.9 & 1 & 328.9 & 46.78 & $<0.0001$ & -3.7 \\
\hline $\begin{array}{l}\text { C-Ethanol } \\
\text { Concentration }\end{array}$ & 1253.7 & 1 & 1253.7 & 178.3 & $<0.0001$ & -7.23 \\
\hline $\mathrm{AB}$ & 1.49 & 1 & 1.49 & 0.21 & 0.6481 & 0.35 \\
\hline $\mathrm{AC}$ & 1.49 & 1 & 1.49 & 0.21 & 0.6481 & -0.35 \\
\hline $\mathrm{BC}$ & 339.69 & 1 & 339.69 & 48.31 & $<0.0001$ & -5.32 \\
\hline $\mathrm{A}^{2}$ & 0.18 & 1 & 0.18 & 0.026 & 0.8731 & 0.13 \\
\hline $\mathrm{B}^{2}$ & 8.3 & 1 & 8.3 & 1.18 & 0.2853 & -0.87 \\
\hline $\mathrm{C}^{2}$ & 526 & 1 & 526 & 74.81 & $<0.0001$ & -6.89 \\
\hline Residual & 232.03 & 33 & 7.3 & & & \\
\hline Lack of Fit & 180.06 & 27 & 6.67 & 0.77 & 0.7087 & \\
\hline Pure Error & 51.97 & 6 & 8.66 & & & \\
\hline Cor Total & 2730.91 & 44 & & & & \\
\hline \multicolumn{7}{|l|}{ Model } \\
\hline Std. Dev. & 2.65 & & & R-Squared & & 0.9147 \\
\hline Mean & 58.62 & & & Adj R-Squared & & 0.8915 \\
\hline C.V. $\%$ & 4.52 & & & Pred R-Squared & & 0.8461 \\
\hline \multirow{3}{*}{$\begin{array}{l}\text { PRESS } \\
-2 \text { Log } \\
\text { Likelihood }\end{array}$} & 418.88 & & & Adeq Precision & & 21.031 \\
\hline & 201.51 & & & $\mathrm{BIC}$ & & 247.19 \\
\hline & & & & $\mathrm{AICc}$ & & 235.26 \\
\hline
\end{tabular}

Table 5 Analysis of variance and model summary for response surface quadratic model for \% ABTS scavenging activity of kalumpit extract

\begin{tabular}{|c|c|c|c|c|c|c|}
\hline Source & $\begin{array}{c}\text { Sum of } \\
\text { Squares }\end{array}$ & df & $\begin{array}{c}\text { Mean } \\
\text { Square }\end{array}$ & F Value & $\begin{array}{c}\text { p-value } \\
\text { Prob > F }\end{array}$ & $\begin{array}{c}\text { Coefficient } \\
\text { Estimate }\end{array}$ \\
\hline Block & 82.18 & 2 & 41.09 & & & \\
\hline Model & 28255.97 & 9 & 3139.55 & 23.23 & $<0.0001$ & \\
\hline A-Temperature & 3021.45 & 1 & 3021.45 & 22.36 & $<0.0001$ & 11.22 \\
\hline B-Solvent to sample ratio & 11973.86 & 1 & 11973.86 & 88.61 & $<0.0001$ & -22.34 \\
\hline C-Ethanol Concentration & 3392.86 & 1 & 3392.86 & 25.11 & $<0.0001$ & -11.89 \\
\hline $\mathrm{AB}$ & 61.39 & 1 & 61.39 & 0.45 & 0.505 & 2.26 \\
\hline $\mathrm{AC}$ & 158.21 & 1 & 158.21 & 1.17 & 0.2871 & -3.63 \\
\hline $\mathrm{BC}$ & 1658.43 & 1 & 1658.43 & 12.27 & 0.0013 & 11.76 \\
\hline $\mathrm{A}^{2}$ & 1337.17 & 1 & 1337.17 & 9.9 & 0.0035 & -10.99 \\
\hline $\mathrm{B}^{2}$ & 4.68 & 1 & 4.68 & $3.50 \mathrm{E}-02$ & 0.8535 & 0.65 \\
\hline $\mathrm{C}^{2}$ & 6958.84 & 1 & 6958.84 & 51.5 & $<0.0001$ & -25.06 \\
\hline Residual & 4459.16 & 33 & 135.13 & & & \\
\hline Lack of Fit & 2326.34 & 27 & 86.16 & 0.24 & 0.9954 & \\
\hline Pure Error & 2132.82 & 6 & 355.47 & & & \\
\hline Cor Total & 32797.32 & 44 & & & & \\
\hline \multicolumn{7}{|l|}{ Model Summary } \\
\hline Std. Dev. & 11.62 & & \multicolumn{3}{|c|}{ R-Squared } & 0.8637 \\
\hline Mean & 37.71 & & \multicolumn{3}{|c|}{ Adj R-Squared } & 0.8265 \\
\hline C.V. $\%$ & 30.83 & & \multicolumn{3}{|c|}{ Pred R-Squared } & 0.7663 \\
\hline PRESS & 7646.64 & & \multicolumn{3}{|c|}{ Adeq Precision } & 13.395 \\
\hline -2 Log Likelihood & 334.53 & & \multirow{2}{*}{\multicolumn{3}{|c|}{$\begin{array}{l}\mathrm{BIC} \\
\mathrm{AICc}\end{array}$}} & 380.21 \\
\hline & & & & & & 368.28 \\
\hline
\end{tabular}

\section{Response surface model of \% ABTS radical scavenging activity of Kalumpit Extract}

Table 5 shows the ANOVA table for the special quadratic model for $\%$ ABTS radical scavenging activity with an $\mathrm{R}^{2}$ of 0.8637 . The Model F-value of 23.23 implies that the model is significant $(p<0.05)$ and there is only a $0.01 \%$ chance that an F-value this large could occur due to noise. The "Lack of Fit F-value" of 0.24 implies that the Lack of Fit is not significant $(p>0.05)$ relative to the pure error and there is a $99.54 \%$ chance that a "Lack of Fit F-value" this large could occur due to noise. Moreover, the model's "Adeq precision" of 13.395 indicates an adequate signal to noise ratio and that the model can be used to navigate the design space.

Equation 5 and Table 5 describe the special quadratic model for $\%$ ABTS scavenging activity of kalumpit extract. The linear effects of temperature, S/S ratio, ethanol concentration, interactive effect of $\mathrm{S} / \mathrm{S}$ ratio and ethanol concentration, and quadratic effects of extraction temperature and ethanol concentration were found to significantly influence the \% ABTS scavenging activity of kalumpit extract $(p<0.05)$. Moreover, the linear effect of extraction temperature and interactive effect of $\mathrm{S} / \mathrm{S}$ ratio and ethanol concentration on $\%$ ABTS scavenging activity of kalumpit extract were observed to be significantly positive as evidenced by their coefficient estimate values of 11.22 and 11.76 , respectively. Figure $3 \mathrm{~A}$ shows that a high \% ABTS scavenging activity of kalumpit extract can be observed in midpoint level of extraction temperature. The positive effect of temperature can be attributed to the reduced viscosity and surface tension of the solvent, resulting in higher phenolic solubility, extraction and diffusion rate, and antioxidant activity (Ju and Howard, 2003; Piovesan $\boldsymbol{e}$ al., 2017). This was also found to be consistent with Lee $\boldsymbol{e t}$ al. (2016) report on the significant positive effect of extraction temperature on the \% DPPH scavenging activity of Korean red ginseng extract. Figure $4 \mathrm{C}$ show that a high $\%$ ABTS scavenging activity of kalumpit extract can be observed in low-level S/S ratio and midpoint-level of ethanol concentration. Although insignificant, the interaction between temperature and $\mathrm{S} / \mathrm{S}$ ratio also have positive effects as shown in Figure $4 \mathrm{~A}$ and confirmed by a coefficient estimate of 2.26 (Table 5). A 
medium level \% ABTS scavenging activity of kalumpit extract can be observed at midpoint-level of extraction temperature and low-level $\mathrm{S} / \mathrm{S}$ ratio.

On the other hand, the linear terms of S/S ratio and ethanol concentration, and the quadratic terms of extraction temperature and ethanol concentration, were found to have significant negative effects on the $\%$ ABTS scavenging activity of kalumpit extract. In this regard, a high \% ABTS scavenging activity of kalumpit extract can be observed at midpoint level of extraction temperature (Figure 3A), low-level S/S ratio (Figure 3B) and midpoint-level of ethanol concentration (Figure 3C). The linear significant negative effects of S/S ratio and ethanol concentration agrees with Cheok $\boldsymbol{e t}$ al. (2012) report on the negative effects of S/S ratio and methanol concentration on total phenolic content of Garcinia mangostana Linn. hull. On the other hand, the significant quadratic effect of the ethanol concentration on \% ABTS scavenging activity of kalumpit extract is consistent with Lee et al. (2016) and Liyana-Pathirana and Shahidi (2005) report on the significant negative effect of ethanol concentration quadratic term on antioxidant activity of Korean red ginseng and hard wheat, respectively. Interaction between extraction temperature and ethanol concentration also had an insignificant negative effect on the \% ABTS scavenging activity of kalumpit extract, as demonstrated by its coefficient estimate of -3.63 . An intermediate \% ABTS scavenging activity of kalumpit extract can be observed at midpoint level of extraction temperature and ethanol concentration as shown in Figure 4B.

$\%$ ABTS Scavenging Activity $=+56.59+11.22 \mathrm{~A}-22.34 \mathrm{~B}-11.89 \mathrm{C}+2.26 \mathrm{AB}-$ $3.63 \mathrm{AC}+11.76 \mathrm{C}-10.99 \mathrm{~A}^{2}+0.65 \mathrm{~B}^{2}-25.06 \mathrm{C}^{2}$

Equation 5

Where $\mathrm{A}, \mathrm{B}$, and $\mathrm{C}$ denote temperature, $\mathrm{S} / \mathrm{S}$ ratio and $\%$ ethanol concentration, respectively.
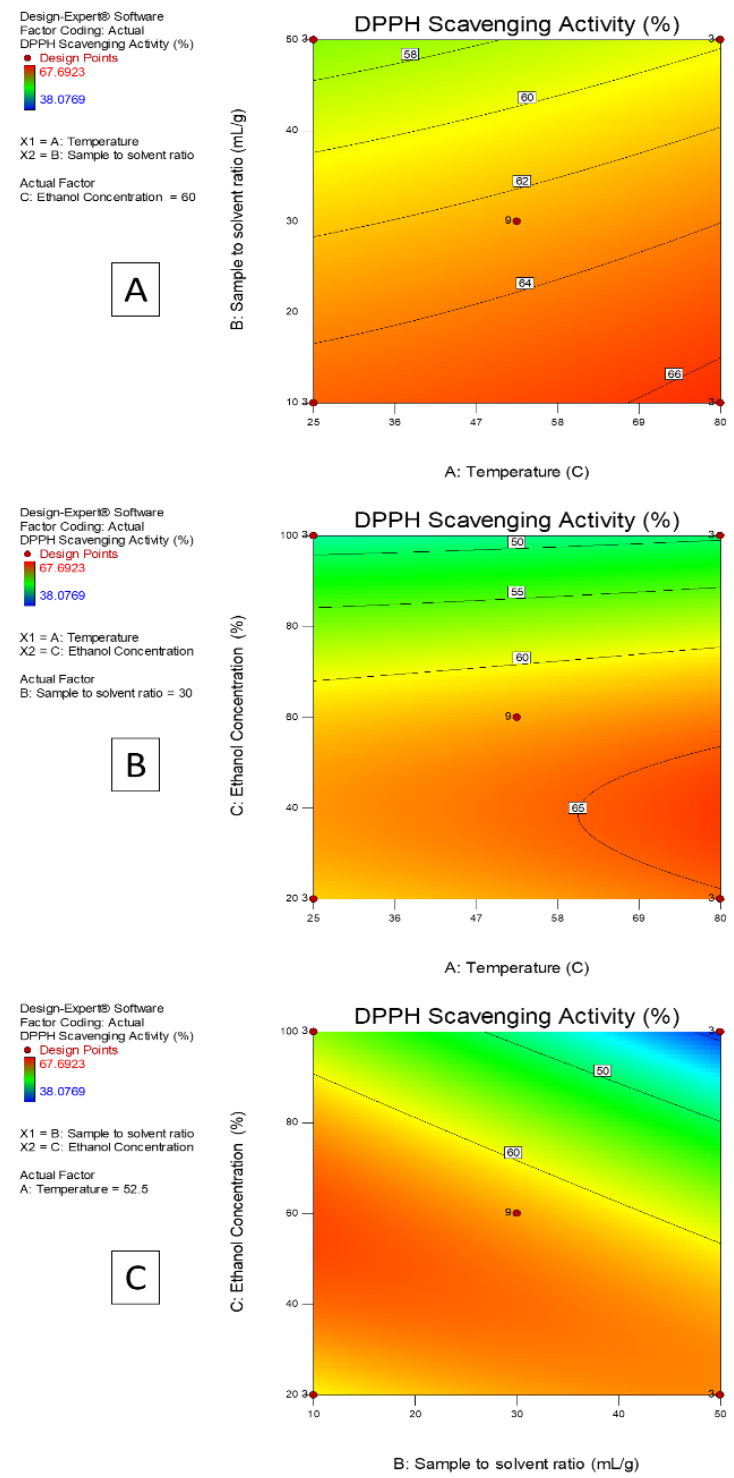

Figure 2 Contour plots for interaction effects of extraction temperature and solvent to sample ratio (A), temperature and ethanol concentration (B), and solvent to sample ratio and ethanol concentration (C) on \% DPPH scavenging activity of kalumpit extract
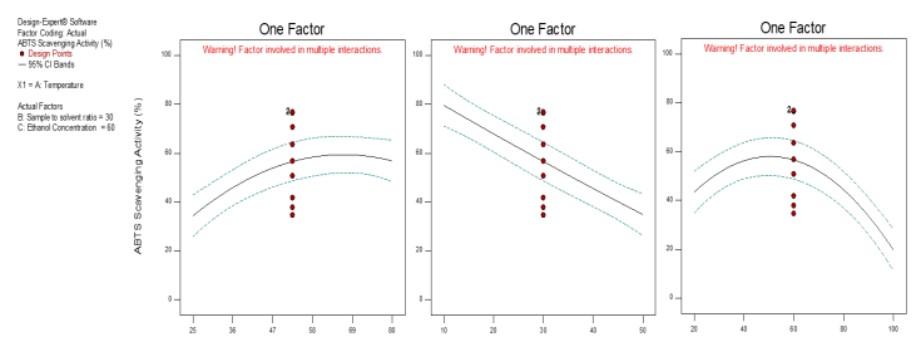

Figure 3 Model graphs for linear effects of extraction temperature (A), solvent to sample ratio (B) and ethanol concentration (C) on \% ABTS scavenging activity of kalumpit extract
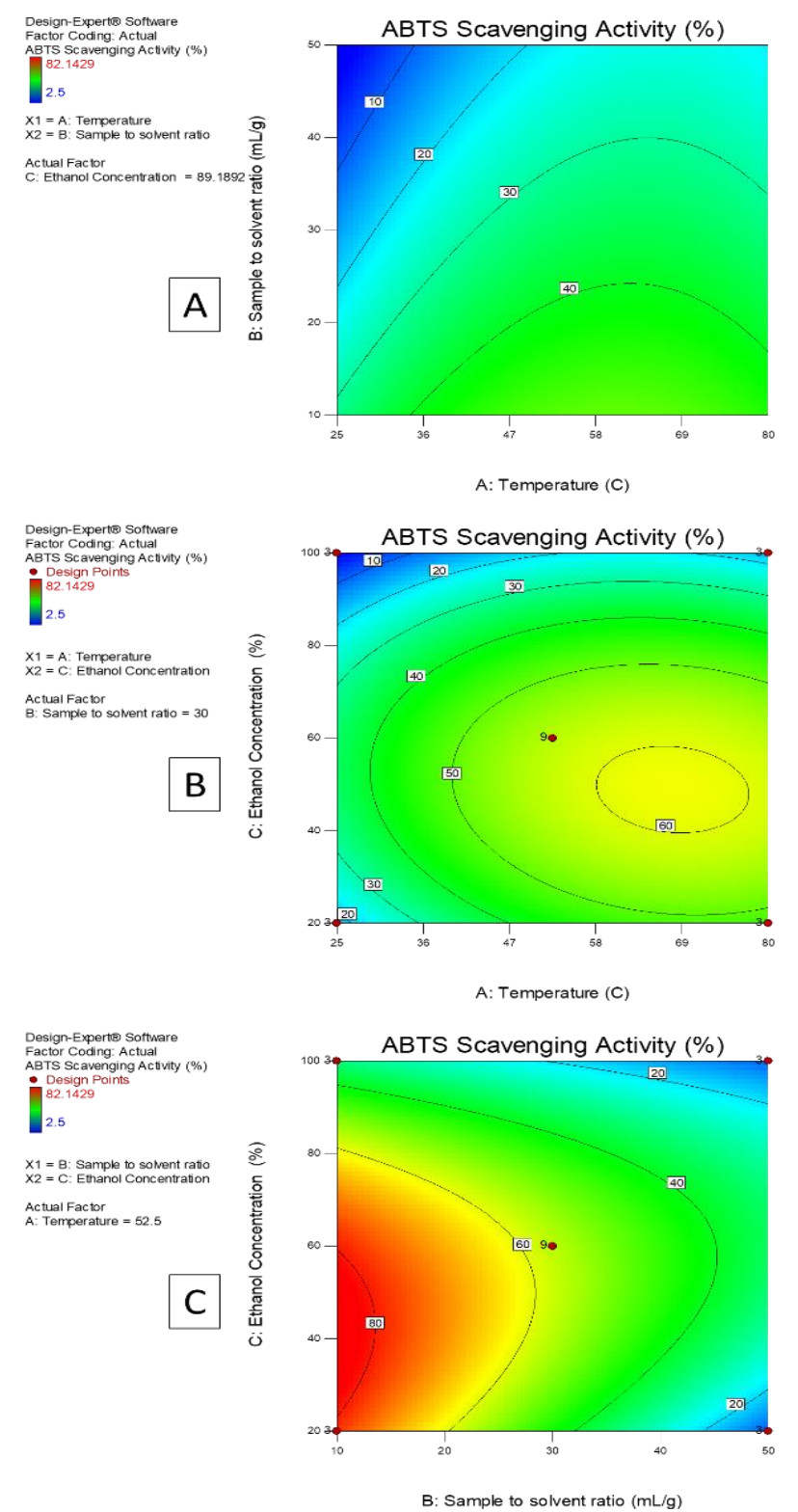

Figure 4 Contour plots for interaction effects of extraction temperature and solvent to sample ratio (A), temperature and ethanol concentration (B), and solvent to sample ratio and ethanol concentration (C) on \% ABTS scavenging activity of kalumpit extract

\section{Optimization and validation of extraction models developed}

Ultimately, the models for \% DPPH and ABTS radical scavenging activities of kalumpit fruit extract were confirmed to adequately fit the response surface, hence, no evidence supports the claim that the model does not adequately explain the variation in the response. The composite desirability of 0.977 is indicative that the settings for the factors achieved favorable results for all responses as a whole and the goal for optimization was satisfied. A desirability function 
approach as a numerical optimization technique was used to determine the optimum extraction condition where the highest \% DPPH and ABTS radical scavenging activities of kalumpit fruit extract were attained. Constraints were defined as the lower and upper limit range of extraction temperature, S/S ratio and ethanol concentration to attain maximum \% DPPH and ABTS radical scavenging activities and desirability. Based on the numerical optimization with the desirability function and the constraints given above, the optimum condition of extraction was attained at the extraction temperature of $80.0^{\circ} \mathrm{C}, \mathrm{S} / \mathrm{S}$ ratio of 10 $\mathrm{mL} \mathrm{g}^{-1} \mathrm{~min}$ and ethanol concentration of $51.66 \%$, which resulted in the maximum desirability value of 0.977 , and predicted \% DPPH and ABTS radical scavenging activities of 66.63 and 82.14 , respectively.

The adequacy of the predictive models at the optimum condition was validated by performing 3 independent experiments while the experimental data were compared with the predicted values (Table 6). No significant difference was found between experimental data and predicted values $(p>0.05)$ indicating that the models developed were adequate to describe the relationship between the factors and responses. Moreover, less than 5\% error was observed for both response parameters.

Table 6 T-test analysis for validation of the optimized conditions for extraction of antioxidants from kalumpit.

\begin{tabular}{cccccc}
\hline Response Parameter & Predicted & Experimental & t- Value & p-Value & \% Error \\
\hline \% DPPH scavenging activity & $66.63 \pm 2.65$ & $67.66 \pm 2.05$ & -0.53 & 0.632 & 1.54 \\
\% ABTS scavenging activity & $82.10 \pm 11.60$ & $78.98 \pm 6.57$ & 0.41 & 0.709 & -3.80 \\
\hline
\end{tabular}

\section{CONCLUSION}

The results showed that temperature, S/S ratio and \% ethanol are significant factors that affect the extraction of antioxidants from kalumpit. In addition, optimum \% DPPH and ABTS radical scavenging activities of kalumpit extract were generally obtained at high-level extraction temperature, low-level S/S ratio and midpoint-level ethanol concentration. Predictive models adequately described the \% DPPH and ABTS radical scavenging activities of kalumpit extract as a function of independent factors. The desirability function approach determined the optimum conditions for the extraction of kalumpit resulting in maximum \% DPPH and ABTS radical scavenging activities. The optimum conditions for the solvent extraction of antioxidants were attained at the extraction temperature of $80.0{ }^{\circ} \mathrm{C}, \mathrm{S} / \mathrm{S}$ ratio of $10 \mathrm{~mL} \mathrm{~g}^{-1} \mathrm{~min}$ and ethano concentration of $51.66 \%$ resulting in the maximum desirability value of 0.977 and predicted \% DPPH and ABTS radical scavenging activities of 66.63 and 82.14 , respectively. The baseline data generated by this research is useful in maximizing the potential of kalumpit, through the production of high-value food ingredients from kalumpit such as health promoting antioxidants and natural colorants.

Acknowledgment: Authors are grateful to UP OVPAA-ECWRG (University of the Philippines Office of the Vice President for Academic Affairs- Enhanced Creative Work and Research Grant) for providing economical support.

\section{REFERENCES}

Alara, O.R., Abdurahman, N.H., \& Olalere, O.A. (2017). Ethanolic extraction of flavonoids, phenolics and antioxidants from Vernonia amygdalina leaf using twolevel factorial design. Journal of King Saud University - Science, 32(1), 7-16. https://doi.org/10.1016/j.jksus.2017.08.001

Alberti, A., Zielinski, A.A., Zardo, D.M., Demiate, I.M., Nogueira, A., \& Mafra, L.I. (2014). Optimisation of the extraction of phenolic compounds from apples using response surface methodology. Food Chemistry, 149, 151-158. https://doi.org/10.1016/j.foodchem.2013.10.086

Amyrgialakia, E., Makrisb, D.P., Mauromoustakos, A., \& Kefalas, P. (2014) Optimisation of the extraction of pomegranate (Punica granatum) husk phenolics using water/ethanol solvent systems and response surface methodology. Industrial Crops and Products, 59,216-222. http://dx.doi.org/10.1016/j.indcrop.2014.05.011

Benmeziane, F., Djamai, R., Cadot, Y., \& Seridi, R. (2014). Optimization of extraction parameters of phenolic compounds from Algerian fresh table grapes, (Vitis vinifera). International Food Research Journal, 21(3), 1061-1065.

Belwal, T., Dhyani, P., Bhatt, I.D., Rawal, R.S., \& Pande, V. (2016) Optimization extraction conditions for improving phenolic content and antioxidant activity in Berberis asiatica fruits using response surface methodology (RSM). Food Chemistry, 207, 115-124. http://doi:10.1016/j.foodchem.2016.03.081

Cacace, J.E., \& Mazza, G. (2002). Extraction of anthocyanins and other phenolics from black currants with sulfured water. Journal of Agricultural and Food Chemistry, 50, 5939-5946. http://10.1021/jf025614x

Cacace, J.E., \& Mazza, G. (2003). Mass transfer process during extraction of phenolic compounds from milled berries. Journal of Food Engineering, 59, 379 389. https://doi.org/10.1016/S0260-8774(02)00497-1

Chen, M., Zhao, Y., \& Yu, S. (2015). Optimisation of ultrasonic-assisted extraction of phenolic compounds, antioxidants, and anthocyanins from sugar beet molasses. Food Chemistry, 172, 543-550. http://10.1016/i.foodchem.2014.09.110

Cheok, C.Y., Chin, N.L., Yusof, Y.A., Taliba, R.A., \& Law, C.L. (2012). Optimization of total phenolic content extracted from Garcinia mangostana Linn. hull using response surface methodology versus artificial neural network. Industrial Crops and Products, 40(1), 247-253. http://10.1016/i.indcrop.2012.03.019

Chew, K.K., Khoo, M.Z., Ng, S.Y., Thoo, Y.Y., Wan Mustapha, W.A., \& Ho, C.W. (2011). Effect of ethanol concentration, extraction time and extraction temperature on the recovery of phenolic compounds and antioxidant capacity of
Orthosiphon stamineus extracts. International Food Research Journal, 18(4), 1427-1435.

Coronel, R. (2011). Important and Underutilized Edible Fruits of the Philippines Philippines: University of the Philippines Los Baños Foundation, Inc., and Department of Agriculture-Bureau of Agricultural Research.

Dela Cruz, R.T. (2012). Promoting the Less-Known, Phytochemical-Rich Pinoy Fruits. BAR Research and Development Digest, 14(4), 4-5.

De Leon, D.R.A. (2012). Simply Kalumpit. BAR Research and Development Digest, 14(4), 9-10.

Department of Agriculture of the Philippines. (1996). Philippines: Country report to the FAO International Technical Conference on Plant Genetic Resources Leipzig, Germany. 132 p.

Embuscado, M.E. (2015). Herbs and spices as antioxidants for food preservation In F. Shahidi (Ed.), Handbook of antioxidants for food preservation (pp. 251 280). Amsterdam: Woodhead Publishing.

Galili, S., \& Hovav, R. (2014). Determination of Polyphenols, Flavonoids, and Antioxidant Capacity in Dry Seeds. In R. Watson (Ed.), Polyphenols in Plants Isolation, Purification and Extract Preparation (pp. 305-316). London: Academic Press.

Garcia, V.V., Magpantay, T.O., \& Escobin, L.D. (2005). Antioxidant Potential of Selected Philippine Vegetables and Fruits. The Philippine Agricultural Scientist 88(1), 78-83.

Guan, J., He, J., Shen, C., Li, L., Wang, Y., \& Cheng, Y. (2015). How cultivars influence fruit composition: total phenols, flavonoids contents, and antioxidan activity in the pulp of selected Asian pears. In V. Preedy (Ed.), Processing and impact on active components in foods (pp. 139-145). London: Academic Press https://doi.org/10.1016/B978-0-12-404699-3.00017-2

He, B., Zhang L., Yue, X., Liang, J., Jiang, J., Gao, X., \& Yue, P. (2016) Optimization of ultrasonic-assisted extraction of phenolic compounds and anthocyanins from blueberry (Vaccinium ashei) wine pomace. Food Chemistry, 204, 70-76. http://10.1016/j.foodchem.2016.02.094

Hijazi A., Al Masri D.S., Farhan, H., Nasser, M. Rammal, H., \& Annan, H. (2015). Effect of different ethanol concentrations, using different extraction techniques, on the antioxidant capacity of Lebanese Eryngium creticum. Journal of Pharmaceutical, Chemical and Biological Sciences, 3(2), 262-271.

Ilaiyaraja, N., Likhith, K.R., Sharath Babu, G.R., \& Khanum, F. (2015) Optimisation of extraction of bioactive compounds from Feronia limonia (wood apple) fruit using response surface methodology (RSM). Food Chemistry, 173, 348-354.http://dx.doi.org/10.1016/j.foodchem.2014.10.035

Ju, Z.Y., \& Howard, L.R. (2003). Effects of solvent and temperature on pressurized liquid extraction of anthocyanins and total phenolics from dried red grape skin. Journal of Agricultural and Food Chemistry, 51(18), 5207-5213. http://dx.doi.org/10.1021/jf0302106

Karacabey, E., \& Mazza, G. (2010). Optimisation of antioxidant activity of grape cane extracts using response surface methodology. Food Chemistry, 119, 343 348. http://doi:10.1016/j.foodchem.2009.06.029

Kemerli-Kalbaran, T., \& Ozdemir, M. (2019). Multi-response optimization of oil extraction from pine nut (Pinus pinea L.) by response surface methodology: Extraction efficiency, physicochemical properties, and antioxidant activity. LWT Food Science and Technology, 103, 34-43. https://doi.org/10.1016/j.lwt.2018.12.067

Langenberger, G., Prigge, V., Martin, K., Belonias, B., \& Sauerborn, J. (2009) Ethnobotanical knowledge of Philippine lowland farmers and its application in $\begin{array}{llll}\text { agroforestry. } & \text { Agroforestry } & \text { Systems, } & \text { 76, }\end{array}$ https://doi.org/10.1007/s10457-008-9189-3

Lee, J.W., Mo, E.J., Choi, J.E., Jo. Y.H., Jang, H., Jeong, J.Y., Jin, Q., Chung, H.N., Hwang, B.Y., \& Lee, M.K. (2016). Effect of Korean red ginseng extraction conditions on antioxidant activity, extraction yield, and ginsenoside Rg1 and phenolic content: optimization using response surface methodology. Journal of Ginseng Research, 40, 229-236. http://dx.doi.org/10.1016/j.jgr.2015.08.001

Li, H., Deng, Z., Wu, T., Liu, R., Loewen, S., \& Tsao, R. (2012). Microwaveassisted extraction of phenolics with maximal antioxidant activities in tomatoes. Food Chemistry, 130(4), 928-936 http://dx.doi.org/10.1016/j.foodchem.2011.08.019 
Li, Y. Cao, S.Y., Lin, S.J., Zhang, J.R., Gan, R.Y., \& Li, H.B. (2019). Polyphenolic profile and antioxidant capacity of extracts from Gordonia axillaris fruits. Antioxidants, 8(6), 150. https://doi.org/10.3390/antiox 8060150

Liyana-Pathirana, C., \& Shahidi, F. (2005). Optimization of extraction of phenolic compounds from wheat using response surface methodology. Food Chemistry, 93, 47-56. http://doi:10.1016/j.foodchem.2004.08.050

Mokrani, A., \& Madani, K. (2016). Effect of solvent, time, and temperature on the extraction of phenolic compounds and antioxidant capacity of peach (Prunus persica L.) fruit. Separation and Purification Technology, 162, 68-76. https://doi.org/10.1016/j.seppur.2016.01.043

Montgomery, D.C. (2013). Design and Analysis of Experiments 8th ed. Canada: John Wiley and Sons Inc.

Piovesan, N., Viera, V.B., Mello, R. de O., Santos, R.C.V. dos., Vaucher, R. de A., Dressler, V.L, Bizzi, C.A., \& Fries, L.L.M. (2017). Microwave-assisted extraction of bioactive compounds from blueberry (Vaccinium ashei Reade) and their antioxidant and antimicrobial capacity. International Food Research Journal, 24(6), 2526-2533.

Pokorny, J. (2007). Antioxidants in Food Preservation. In M.S. Rahman (Ed.), Handbook of food preservation (pp. 259-286). Boca Raton: CRC Press.

Pompeu, D.R., Silva, E.M., \& Rogez, H. (2009). Optimization of the solvent extraction of phenolic antioxidants from fruits of Euterpe oleracea using response surface methodology. Bioresource Technology, 100, 6076-6082. https://10.1016/j.biortech.2009.03.083

Ragasa, C.Y., Torres, O.B., Mandia, E.H., \& Shen, C.C. (2014). Chemical constituents of Terminalia microcarpa Decne. Der Pharmacia Lettre, 6(6), 439442 .

Ramis-Ramos, G. (2003). Synthetic Antioxidants. In P. Finglas, F. Toldra, \& B. Caballero (Eds.), Encyclopedia of food sciences and nutrition (2nd Edition) (pp. 265-275). Academic Press. https://doi.org/10.1016/B0-12-227055-X/00054-7

Re, R., Pellegrini, N., Proteggente, A., Pannala, A., Yang, M., \& Rice-Evans, C. (1999). Antioxidant activity applying an improved ABTS radical cation decolorization assay. Free Radical Biology and Medicine, 26(9-10), 1231-1237. https://doi.org/10.1016/S0891-5849(98)00315-3

Rezaei, S., Rezaei, K., Maryam, H., \& Mohsen, L. (2013). Solvent and solvent to sample ratio as main parameters in the microwave-assisted extraction of polyphenolic compounds from apple pomace. Food Science and Biotechnology, 22, 1269-1274. https://doi.org/10.1007/s10068-013-0212-8

Rodriguez-Amaya, D.B. (2015). Carotenes and xanthophylls as antioxidants. In F. Shahidi (Ed.), Handbook of antioxidants for food preservation (pp. 17-39) Amsterdam: Woodhead Publishing.

Sanchez, P.C., Dizon, E.I., \& Ocampo, T.A. (1976). Utilization of Calumpit (Terminalia edulis Linn.) as food. Philippine Journal of Crop Science, 1(2), 7477.

Santiago, D.M., Garcia, V., Dizon, E., \& Merca, F. (2007). Antioxidant activities, flavonol and flavanol content of selected Southeast Asian indigenous fruits. The Philippine Agricultural Scientist, 90(2), 123-130

Shahidi, F. (2015). Antioxidants: principles and applications. In F. Shahidi (Ed.), Handbook of antioxidants for food preservation (pp. 1-12). Amsterdam: Woodhead Publishing.

Sharmila, G., Nikitha, V., Ilaiyarasi, S., Dhivya, K., Rajasekar, V., Kumar, N., Muthukumaran, K., \& Muthukumaran, C. (2016). Ultrasound assisted extraction of total phenolics from Cassia auriculata leaves and evaluation of its antioxidant activities. Industrial Crops and Products, 84, 13-21. https://doi.org/10.1016/j.indcrop.2016.01.010

Silva, E., Rogez, H., \& Larondelle, Y. (2007). Optimization of extraction of phenolics from Inga edulis leaves using response surface methodology. Separation and Purification Technology, 55(3), 381-387. https://doi.org/10.1016/j.seppur.2007.01.008

Ungson, L.B. (2001). Character variation in Terminalia microcarpa Decne. morphology and phenology of mature trees and early seedling growth. Asian International Journal of Life Sciences, 10(1), 45-54.

Vaji'c, U. J., Gruji'c-Milanovi'c, J., Zivcovic, J., Savikin, K., Godevac, D. Miloradovi'c, Z., Bugarski, B., \& Mihailovi'c-Stanojevica, N. (2015). Optimization of extraction of stinging nettle leaf phenolic compounds using response surface methodology. Industrial Crops and Products, 74, 912-917. https://doi.org/10.1016/j.indcrop.2015.06.032

Vatai, T., Škerget, M., \& Knez, Z. (2009). Extraction of phenolic compounds from elder berry and different grape marc varieties using organic solvents and/or supercritical carbon dioxide. Journal of Food Engineering, 90(2), 246-254 http://dx.doi.org/10.1016/j.jfoodeng.2008.06.028

Yuan, Q., Xie, Y., Wang, W., Yan, Y., Ye, H., \& Jabbar, S. (2015). Extraction optimization, characterization, and antioxidant activity in vitro of polysaccharides from mulberry (Morus alba L.) leaves. Carbohydrate Polymers, 128, 52-62. https://doi.org/10.1016/j.carbpol.2015.04.028

Weuster-Botz, D. (2000). Experimental design for fermentation of media development: statistical design or global random search? Journal of Bioscience and Bioengineering, 90(5), 473-483. https://doi.org/10.1016/S13891723(01)80027-X
Zhu, Q., Robert, M., Jodi, L., Roberta, R., \& Carl, L. (2002). Antioxidant activities of oolong tea. Journal of Agricultural and Food Chemistry, 50, 6929. 6934. http://10.1021/jf0206163 